2. Hrinchenko, M. (1922). Istoriia ukrainskoi muzyky [History of Ukrainian music]. Lviv, $350 \mathrm{p}$. [in Ukrainian].

3. Novynky (1885). [News]. Work. Lviv, part 17, p. 3. [in Ukrainian].

4. Novynky (1886). [News]. Work. Lviv, part 4, p. 3. [in Ukrainian].

5. Novynky (1890). [News]. Work. Lviv, part 63, p. 2. [in Ukrainian].

6. Novynky (1892). [News]. Work. Lviv, part 250. [in Ukrainian].
7. Novynky (1893). [News]. Work. Lviv, part 142. [in Ukrainian].

8. Zaleskyi, O. (1927). Ukrainski muzychni vydavnytstva v Halychyni [Ukrainian music publishing houses in Galicia]. Music. Work. Lviv, part 1, pp. 65-67. [in Ukrainian].

9. Mykhalchyshyn, Ya. (1992). Z muzykoiu kriz zhyttia [With music through life]. Lviv, pp.184-192. [in Ukrainian].

10. Sichynskyi, D. \& Yakubovych, Ye. (1904). Zbirnyk pisen [Collection of songs]. Work. Lviv, part 283. pp. 3-4. [in Ukrainian].

Стаття надійшла до редакції 11.01.2021

УДК 373.016:78.071.1(477)

DOI:

Тетяна Медвідь, кандидат педагогічних наук, доиент кафедри методики музичного виховання та диригування Дрогобицького державного педагогічного університету імені Івана Франка

\title{
РОЛЬ ТВОРЧОЇ СПАДЩИНИ М. ЛИСЕНКА У ФОРМУВАННІ МУЗИЧНОЇ КУЛЬТУРИ УЧНІВСЬКОЇ МОЛОДІ
}

У статті розкрито значення інструментальних, хорових, сиенічних і камерно-вокальних творів М. Лисенка у формуванні музичної культури учнів загальноосвітніх навчальних закладів та висвітлено виховний вплив його музики на розвиток особистості. Проведено аналіз хорових збірок для дітей і творів композитора, запропонованих для слухання та сприймання у загальноосвітніх школах. Розглянуто педагогічну модель їх використання в освітньому процесі та розкрито методику вивчення творів М. Лисенка на уроках музичного мистецтвва.

Ключові слова: музична культура; фольклор; творча спадщина; хорові збірки для дітей; навчальні програми.

Jim. 12.

Tetiana Medvid, Ph.D. (Pedagogy), Associate Professor of Methods of Musical Education and Conducting Department, Drohobych Ivan Franko State Pedagogical University

\section{THE ROLE OF M. LYSENKO'S CREATIVE HERITAGE IN THE FORMATION OF MUSICAL CULTURE STUDENT YOUTH}

The key aspects studying the work of M. Lysenko in secondary schools are reveals in the article. In particular, the importance of instrumental, choral, stage and chamber-vocal works of M. Lysenko in the formation musical culture of students secondary schools is clarified. The educational influence of his music on the development of personality is analyzed. The role of the composer in the public life of the country is revealed, namely in the establishment of the first music and drama school in Ukraine. M. Lysenko's folklore activity is covered and the analysis of choral collections for children is carried out: "Youth" and "Collection of folk songs in the choral schedule adapted for pupils of younger and senior age in folk schools". Their educational significance is revealed and their role in the development of musical culture of schoolchildren is established.

The educational programs "Musical art, grades 1-4" are analyzed (author's team led by L. Khlebnikova) and "Art, 5-9 classes" (author's team under the direction of L. Masol), as well as textbooks "Musical Art", compiled by L. Kondratova, L. Masol, L. Aristova. The works of the composer, offered for listening and perception at music lessons, are singled out. An analysis of M. Lysenko's piano music, children's operas "Goat-dereza", "Mr. Kotsky", "Winter and Spring", as well as lyrical-domestic opera "Natalka Poltavka", heroic-patriotic "Taras Bulba", spiritual work "Prayer for Ukraine" and the cantata "Rejoice, level not watered". The pedagogical model of their use in the educational process of secondary schools is considered and their educational significance is formulated. The 


\section{РОЛЬ ТВОРЧОЇ СПАДЩИНИ М. ЛИСЕНКА У ФОРМУВАННІ МУЗИЧНОЇ КУЛЬТУРИ УЧНІВСЬКОЇ МОЛОДІ}

method of studying M. Lysenko's works is offered, their national color is revealed and their influence on formation of musical culture of the person is covered.

Keywords: music culture; folklore; creative heritage; choral collections for children; educational programms.

$\Pi$ остановка проблеми. Одним із важливих завдань музичноестетичного виховання узагальноосвітніх закладах є підвищення музичної культури підростаючого покоління, розширення їх музичного світогляду. Цьому сприяє виконання, сприймання та інтерпретація кращих зразків української та світової музики, а також формування емоційноціннісного ставлення до мистецтва [7; 8]. Музичне мистецтво завжди орієнтоване на відображення духовної культури народу й конкретної людини як іiі носія. У розвитку української музичної культури постать Миколи Лисенка, безумовно, займає провідне місце. Адже своєю багатогранною діяльністю він підняв українську музику на високий щабель світової музичної культури, збагативши ії скарбами українських народних мелодій. Тому розкриття значення творчої спадщини М. Лисенка дуже важливе у контексті формування музичної культури учнівської молоді.

Аналіз останніх досліджень і публікацій. Життєвий і творчий шлях, громадську та фольклористичну діяльність М. Лисенка досліджували багато видатних композиторів, музикознавців, науковців, зокрема Л. Архімович, Т. Булат, В. Дяченко, 3. Василенко, М. Гордійчук, М. Загайкевич, Ф. Колесса, Н. Костюк, С. Людкевич, А. Муха, Д. Ревуцький, I. Сікорська, Р. Скорульська, Є. Товстуха, В. Чаговець, 3. Штундер та ін. Цікаві відомості з життя та факти творчих взаємозв'язків композитора з видатними діячами кіния $X I X-$ початку $X X \mathrm{~cm}$. описує син славетного музиканта - О. Лисенко. Музичнопедагогічну діяльність та внесок М. Лисенка у теорію й практику загальної музичної освіти України розглядають І. Околович, О. Михайличенко, С. Процик, Л. Сбітнева та ін. Хорову творчість, зокрема й духовну хорову спадщину в різних аспектах, аналізують С. Глушкова, О. Макаренко, Л. Філатова, М. Хіміч, М. Юрченко та ін. Характеристику оперної творчості та конкретних оперних творів подають Н. Андрієвська, Л. Архімович, І. Ізваріна, В. Харитонова та ін. Однак роль творчої спадщини М. Лисенка у формуванні музичної культури учнівської молоді досліджено недостатньо. Тому актуальність таких розвідок на сучасному етапі освітньої реформи, потреба сучасного українського суспільства у формуванні високого рівня музичної культури підростаючого покоління, впровадження у практику загальноосвітньої школи педагогічної моделі аналізу творів славетного сина Полтавщини зумовило вибір дослідження.

Мета статті - висвітлити значення творчої спадщини М. Лисенка у формуванні музичної культури підростаючого покоління і акцентувати увагу на виховному впливі творів композитора на розвиток особистості.

Виклад основного матеріалу. Видатний український композитор Микола Лисенко (18421912) відомий як фундатор національної музичної освіти, засновник першої музично-драматичної школи, хоровий диригент, піаніст, педагог, музичногромадський діяч та фольклорист. Вагоме місце у його доробку посідають твори, написані під впливом творчості Т. Шевченка, зокрема цикл пісень "Музика до "Кобзаря". Робота над музикою на вірші поета започаткувала професійну композиторську діяльність Лисенка. Окрім того, впродовж усього життя він збирав і творчо аранжував народні мелодії. "Народна пісня, народна музична творчість були тією могутньою рікою,...тим неосяжним і мало дослідженим океаном, по якому Лисенко, ще будучи юнаком, спрямував свій творчий шлях, спочатку як збирач дорогоцінних самоцвітів народної творчості, а згодом - вже як досвідчений майстер-творець, що перетворює самоцвіти в прекрасні намиста національної культури" $[11,3]$. Українські пісні звучать у “Фантазії на українські теми”, в операх "Ніч напередодні Різдва", "Утоплена", в опереті “Чорноморці”. Вершиною використання М. Лисенком українських народних мелодій $€$ його опера "Наталка Полтавка" за п’єсою І. Котляревського. А кращою героїко-патріотичною оперою стала монументальна народна музична драма “Тарас Бульба". Також композитор започаткувавжанр дипячоїопери. Вінстворив три опери-казки, які сам називав “оперками”. Це “Козадереза”, “Пан Коцький” та “Зима і Весна” [1].

Великого громадського значення набуло створення за сприянням М. Лисенка музичнодраматичної школи у Києві (1904). У цьому закладі зросла плеяда видатних українських композиторів та педагогів, зокрема В. Верховинець, О. Кошиць, К. Стеценко, Д. Ревуцький. Значення цієї школи у підготовці кадрів було дуже вагомим $[6,13]$. Таким чином, М. Лисенко своєю педагогічною діяльністю заклав основи спеціальної музичної освіти в Україні. Гідними послідовниками його творчих принципів стали М. Леонтович, Я. Степовий, К. Стеценко, С. Людкевич, Л. Ревуцький та багато інших талановитих композиторів. 


\section{РОЛЬ ТВОРЧОЇ СПАДЩИНИ М. ЛИСЕНКА У ФОРМУВАННІ МУЗИЧНОЇ КУЛЬТУРИ УЧНІВСЬКОЇ МОЛОДІ}

Протягом усього життя Микола Віталійович записував фольклор, вивчав його, науково підходячи до народної мелодії та слів, намагаючись точно зафіксувати ладо-інтонаційну будову, метро-ритм і музичну форму. Фольклорні зразки він опублікував окремими збірками, згрупувавши їх за жанрами. Було надруковано п'ять випусків обрядових пісень (дві збірки “Веснянок”, “Купальська справа”, “Колядки та щедрівки”, “Весілля”, “Молодощі” та “Збірник народних українських пісень в хоровому розкладі, пристосованих для учнів молодшого і підстаршого середнього віку в школах народних". Фольклорні збірки М. Лисенка (понад 600 зразків) охоплюють майже всі пісенні жанри: дитячі, жартівливі, календарно-обрядові, побутові, історичні та думи. Серед історичних пісень значне місце займають козацькі, бурлацькі, гайдамацькі, чумацькі, рекрутські та цехові.

З великою любов’ ю працював М. Лисенко над упорядкуванням збірки “Молодощі”. До неї ввійшли 25 дитячих ігрових пісень та 13 веснянок 3 фортепіанним супроводом композитора. Добір пісень та текстові пояснення автора свідчать про те, $з$ якою відповідальністю ставився М. Лисенко до створення цієї збірки. Вона була видана у 1875 р., в період, коли почалася нова хвиля переслідувань українського народу. Також велике значення має “Збірка народних пісень в хоровому розкладі...”. Матеріал ії підібраний з урахуванням вікових музично-психологічних особливостей дітей. Пісні впорядковані відповідно до складності виконання: від одноголосих (іноді з підголосками) до мелодій на два і три голоси. У передмові автор подає короткі відомості про конкретних історичних осіб, зокрема Байду, Дорошенка, Нечая, Максима Залізняка, та підкреслює велику роль народної пісні у вихованні школярів. До збірки ввійшли твори з різних куточків України, зокрема Поділля, Київщини, Черкащини, Чернігівщини, Полтавщини, Миколаївщини, Таврії, Волині тощо [4].

Велике значення у розвитку музичної культури школярів мають фортепіанні твори М. Лисенка. У 70-ті pp. ХІХ ст. композитор створює понад півтора десятка таких творів: два концертні полонези, дві рапсодії на українські теми, сонату і невеликі п’єси - “Елегія”, “Пісні без слів”, “Мрії”, "Мазурка", "Баркарола" тощо. Ознайомившись iз навчальними програмами із музичного мистецтва, можемо побачити, що фортепіанну музику школярі опановують як у початковій, так і в основній школі. Згідно з чинною навчальною програмою “Музичне мистецтво, 1-4 кл.”, учні 2 класу ознайомлюються із фортепіанним твором М. Лисенка “Враження від радісного дня” у темі
“Виражальне та зображальне в музиці”. У 3 класі слухають “Експромт ля мінор" у темі "Музична форма”. У 4 класі школярі знайомляться із “Елегією” та "Баркаролою” у темі “Музика мого народу” [7]. У підручнику “Музичне мистецтво, 6 кл.” (авт. Л. Масол; Л. Аристова), згідно 3 чинною навчальною програмою "Мистецтво, 59 кл.”, учням пропонують для слухання “Елегію для віолончелі та фортепіано” М. Лисенка, а також "Українську сюїту у формі старовинних танців на основі народних пісень” [5; 8].

У фортепіанній музиці Лисенка відчувається вплив Ф. Шопена, Ф. Ліста, а також спостерігається інтерес до фольклорних джерел. Зокрема в “Баркаролі", запропонованій у навчальній програмі для учнів 4 класу, композитор символічно використав українську народну пісню “Пливе човен”, оскільки баркарола походить від італійського слова barka, що означає nicня човняра [9]. Характерний ритмічний малюнок твору та тридольний метр створюють відчуття похитування човна на воді. Учням 2 класу, яким у навчальній програмі пропонують твір М. Лисенка “Враження від радісного дня", можна запропонувати послухати його у виконанні юних піаністів, вихованців музичних шкіл і запитати, які враження від музики вони отримали. Під час обговорення твору звернути увагу на темп, характер та настрій музики. У 3 класі школярі слухають “Експромт ля мінор” М. Лисенка. Потрібно наголосити учням, що експромт - це твір, створений композитором спонтанно, без попередньої підготовки. Музика п’єси заворожує слухачів з перших секунд. Форма твору тричастинна. Мелодія першої та третьої частини бурхлива, емоційна, стрімка. Друга частина яскравого, грайливого характеру, однак не контрастує 3 темами, які їі обрамляють. Слухаючи “Елегію”, можна поспілкуватися 3 учнями 4 класу про ніжний лірико-журливий настрій твору, двочастинну форму 3 невеликою кодою, про теми обох частин, які мають романсовий характер. Варто також сказати школярам, що назва елегія походить від грецького слова elegos, що означає журба [9].

У змісті навчального матеріалу для учнів початкових класів $є$ також фрагменти з трьох дитячих опер (“Коза-дереза”, “Пан Коцький”, “Зима іВесна”. Зокрема, пісня Лисички з опери “Козадереза" (1 клас), інші фрагменти з цієї опери (2 клас), календарно-обрядові пісні та хор “А вже весна" 3 опери “Зима і Весна" (3 клас), фрагменти з опери “Пан Коцький” (4 клас), а також дума Кобзаря з опери “Тарас Бульба" (3 клас) та хор “Гей, не дивуйте, добрії люди” з опери “Тарас Бульба" (4 клас). 


\section{РОЛЬ ТВОРЧОЇ СПАДЩИНИ М. ЛИСЕНКА У ФОРМУВАННІ МУЗИЧНОЇ КУЛЬТУРИ УЧНІВСЬКОЇ МОЛОДІ}

Слухаючи фрагменти дитячих опер на уроках музичного мистецтва, учитель повинен наголосити, що М. Лисенко у цих сценічних творах невипадково використав мелодії українських народних пісень. Композитор добирав їх за змістом і формою так, щоб якомога яскравіше показати риси характеру кожного з персонажів опер, їх зовнішні прикмети, зобразити сюжетну ситуацію, показати побут українського народу тощо. Виховне значення опери "Коза-дереза" полягає в тому, що у ній засуджуються нахабність, насильство, брехливість. Композитор зумів у високохудожній формі, за допомогою глибоко реалістичних засобів музичної виразності, розкрити зміст народної казки. "Мініатюра за своєю будовою, опера М. Лисенка не вимагає ні значного складу виконавців, ні великої сцени і тому може бути поставлена в будь-якій школі, дитячому садку тощо" $[1,21]$. У порівнянні 3 “Козою-дерезою” опера "Пан Коцький” має більш широке суспільне значення. Це сатирична опера. Всі її події й образи взяті з побуту людей та перенесені у світ тварин. Музичні характеристики дійових осіб, особливо пана Коцького й Лисиці, відзначаються іронічним підтекстом. В узагальнених образах Лисиці і пана Коцького за допомогою влучних прийомів пародіювання та алегорії викрито такі людські вади, як ледарство, підлабузництво тощо $[1,22]$. Третя дитяча опера М. Лисенка - “Зима і Весна". В основі сюжету народна фантастична казка про Весну і Зиму, яка тісно переплетена 3 народним українським побутом. Основна ідея опери - поєднання людини з природою, перемога світла над темрявою. Саме у хорі “А вже весна, а вже красна” утверджується оптимістична ідея опери.

На уроках музичного мистецтва учні початкових класів слухають також фрагменти 3 опери “Тарас Бульба” М. Лисенка. Музика опери яскраво свідчить про високу майстерність композитора. Завдяки героїко-патріотичній ідеї, ї̈ талановитому втіленню в художній формі, глибині характерів героїв, правдивості драматичних ситуачій опера ц̆ сьогодні хвилює слухачів. У думі Кобзаря “Ой, кряче ворон сизокрилий”, яку діти слухають у 3 класі, розкрито важке життя українського народу, утиски польської шляхти. У творі М. Лисенко використав типові особливості думного епосу: ритмічно вільний імпровізаційний речитатив, специфічні ладові звороти, лірницький супровід тощо. У темі “Музика мого народу” (4 клас) школярі слухають й аналізують хор запорожців "Гей, не дивуйте, добрії люди" з цієї ж опери. Учитель повинен наголосити, що у хоровому творі М. Лисенко майстерно показав образ козацтва в його багатоманітності, суперечках та єдності. Мелодія хору створена на основі народної історичної пісні часів Богдана Хмельницького і відтворює заклик до боротьби за визволення України від польського гніту.

У 5 класі у темі “Народна музика” учням пропонують для слухання пісню “Засвіт встали козаченьки” з опери “Тарас Бульба” [2]. Учитель має подати більш детальну інформацію щодо опери, повідомити, що вона була створена за сюжетом однойменної повісті М. Гоголя, де висвітлено історичні події часів боротьби козацтва 3 польською шляхтою. Розповідаючи про увертюру до опери, учитель наголошує, що вона $\epsilon$ кращим зразком української симфонічної музики, має героїко-драматичний характер і у ній втілено патріотичні ідеї опери. Характер першої теми закличний, мужній. Затактові сигнали труб у ній - основа лейттеми боротьби народу. Друга тема - широкого пісенного характеру. У третій М. Лисенко використав мелодію української народної пісні “Засвіт встали козаченьки” як тему волелюбного козацтва. Повторення мелодії пісні відбувається у другій дії опери у виконанні чоловічого хору - козаків, які готуються до бою з польським військом.

У темі “Народна музика" учні 5 класу слухають також фрагменти 3 кантати "Радуйся, ниво неполитая" (“Оживуть степи, озера", 5 ч.). Школярі вперше ознайомлюються із жанром кантати, тому учитель пояснює, що значення слова походить від італійського терміну cantare, що означає співати [9]. Кантата "Радуйся, ниво неполитая” - це монументальна п'ятичастинна композиція для солістів, мішаного і жіночого хорів та симфонічного оркестру, написана на текст Т. Шевченка "Ісаія, глава 35 (Подражаніє)". Поет запозичив із Біблії зміст глави 35 пророка Ісаї та створив образ вільної землі, на якій з Божої ласки колись настане прекрасне життя. "Поет і композитор створили омріяний образ вільної України, в щасливе майбуття якої вірили", - пише Л. Філатова [10].

У 6 класі у темі “Жанри камерно-вокальної музики” автори підручника пропонують один 3 кращих духовних творів М. Лисенка - “Молитву за Україну” (“Боже Великий, Сдиний!”) [5]. Він був написаний у 1885 р. на текст відомого українського поета О. Кониського. Цей твір був офіційно визнаний духовним гімном Української православної церкви і “...став виразником віковічних сподівань українського народу, його справжньою “Молитвою за Україну”, - зазначає М. Юрченко $[12,4]$. Окрім церковного гімну, 


\section{РОЛЬ ТВОРЧОЇ СПАДЩИНИ М. ЛИСЕНКА У ФОРМУВАННІ МУЗИЧНОЇ КУЛЬТУРИ УЧНІВСЬКОЇ МОЛОДІ}

композитор написав ще п'ять духовних творів: хоровий концерт “Камо пойду от лиця Твоєго, Господи" на текст 138 псалма Давидового, “Херувимську пісню” на канонічний релігійний текст та три обробки для мішаного хору, зокрема старовинний Різдвяний кондак “Діва днесь пресущественного раждаєт”, псалом “Пречистая Діво, мати Руського краю”; кант Розп'яттю Христову “Хресним древом" [12].

Учням 6 класу також пропонують для слухання "Елегію для віолончелі та фортепіано" M. Лисенка і "Українську сюїту у формі старовинних танців на основі народних пісень” [5]. Перед прослуховуванням "Української сюїти" учитель повинен розповісти учням, що сю̈та (французькою suite) - це циклічна музична форма, укладена з кількох контрастних частин. У цьому творі, як і в багатьох інших, М. Лисенко використовує мелодії народних пісень. Твір складається 3 шести частин, кожна 3 яких має яскраве національне забарвлення.

У 7 класі, згідно з підручником Л. Кондратової, школярі ознайомлюються з оперою М. Лисенка “Наталка Полтавка", зокрема слухають пісню Петра "Сонце низенько" [3]. "Наталка Полтавка" - це кращий зразок лірико-побутової опери. Вона написана за однойменною п'єсою І. Котляревського. Учитель пояснює роль народної пісні (ліричної, танцювально-жартівливої, побутової тощо) у відтворенні різноманітних образів опери. Зокрема, арія Петра “Сонце низенько” належить до жанру пісень-романсів і розкриває найкращі риси українського національного характеру шляхетність, духовність, моральну чистоту. Таким чином, знання музики Миколи Лисенка допоможе особистості сформуватися як патріот своє Батьківщини та збагатить музичну культуру учнівської молоді.

Висновки. У процесі розвитку музичної культури школярів провідну роль відіграє музичне мистецтво завдяки своїй емоційній насиченості та різноманітності, безпосередньому зверненню до внутрішнього світу людини. Оскільки Микола Лисенко чудово усвідомлював велике значення морально-етичного, духовного та естетичного впливу музики на становлення особистості, внесок митця у формування музичної культури дітей та молоді є дуже вагомим. Залучення учнів до скарбниць творчої спадщини композитора допоможе підготувати не тільки естетично розвинених, але духовно збагачених випускників загальноосвітніх закладів. Тому необхідно привчати школярів різного віку слухати й виконувати музику славетного композитора, сприяючи їі емоційному та свідомому сприйняттю.
Однак ця проблема ще недостатньо висвітлена у педагогічних та методичних джерелах, тому потребує подальших наукових досліджень.

\section{ЛIТЕРАТУРА}

1. Андрієвська Н. Дитячі опери М. В. Лисенка. Київ, $1962.76 \mathrm{c}$.

2. Кондратова Л. Музичне мистецтво: підручник, 5 клас. Тернопіль, 2013. 176

3. Кондратова Л. Музичне мистецтво: підручник, 7 клас. Тернопіль, 2015.208

4. Лисенко М. Молодощі : збірка танків та веснянок; Збірка народних пісень в хоровому розкладі пристосованих для учнів молодшого й підстаршого віку у школах народних : ноти. Київ, 1990. 144 с.

5. Масол Л., Аристова Л. Музичне мистецтво: підручник, 6 клас. Харків, 2014. 160.

6. Михайличенко О. Музично-педагогічна діяльність українських композиторів та виконавців другої пол. XIX - поч. XX ст. : історичні нариси. Суми, 2005. 103 с.

7. Навчальна програма для загальноосвітніх навчальних закладів “Музичне мистецтво, 1-4 кл.”. URL: https://mon.gov.ua/ua/osvita/zagalna-serednya-osvita/ navchalni-programi/navchalni-programi-dlyapochatkovoyi-shkoli (дата звернення: 04.02.2021).

8. Навчальна програма для загальноосвітніх навчальних закладів “Мистецтво, 5-9 кл.”. URL: https:// mon.gov.ua/ua/osvita/zagalna-serednya-osvita/ navchalni-programi/navchalni-programi-5-9-klas (дата звернення: 05.02.2021).

9. Словник-довідник музичних термінів (за книгами Ю. Юцевича). URL: http://term.in.ua (дата звернення: 03.02.2021).

10. Філатова Л. Хорова творчість М. В. Лисенка у контексті боротьби інтелігенції проти заборони української мови та культури. Молодь і ринок. 2012. №10 (93). C. $72-76$.

11. Чаговець В. М. В. Лисенко. Київ, 1985. 28 с.

12. Юрченко М. Лисенко М. Релігійні твори для мішаного хору. Дрогобич, 1993. 36 с.

\section{REFERENCES}

1. Andriievska, N.(1962). Dytiachi opery M. V. Lysenka [Children's operas by M.V. Lysenko]. 76 p. [in Ukrainian].

2. Kondratova, L. (2013). Muzychne mystetstvo: pidruchnyk, 5 klas [Musical art: textbook, 5th grade]. $176 \mathrm{p}$. [in Ukrainian].

3. Kondratova, L. (2015). Muzychne mystetstvo: pidruchnyk, 7 klas [Musical art: textbook, 7th grade]. 208p. [in Ukrainian].

4. Lysenko, M. (1990). Molodoshchi : zbirka tankiv ta vesnianok; Zbirka narodnykh pisen v khorovomu rozkladi prystosovanykh dlia uchniv molodshoho y pidstarshoho viku u shkolakh narodnykh : noty [Youth: collection of tanks and spring flowers; Collection of folk songs in the choral schedule adapted for younger and younger students in folk schools: notes.] 144 p. [in Ukrainian].

5. Masol, L., \& Arystova, L. (2014). Muzychne mystetstvo: pidruchnyk, 6 klas [Musical art: textbook, 6 th grade]. 160 p. [in Ukrainian]. 


\section{ПРОФЕСІЙНА ПІДГОТОВКА МАЙБУТНІХ УЧИТЕЛІВ ПОЧАТКОВОЇ ШКОЛИ В КОНТЕКСТІПРІОРИТЕТІВ КОНЦЕПЦЇ̈НУШ}

6. Mykhailychenko, O. (2005). Muzychnopedahohichna diialnist ukrainskykh kompozytoriv ta vykonavtsiv druhoi pol. XIX - poch. XX st. : istorychni narysy [Musical and pedagogical activity of Ukrainian composers and performers of the second floor. XIX - early XX century: historical essays]. 103 p. [in Ukrainian].

7. Navchalna prohrama dlia zahalnoosvitnikh navchalnykh zakladiv "Muzychne mystetstvo, 1-4 kl." [Curriculum for secondary schools "Music, grades 1-4"]. Available at: https://mon.gov.ua/ua/osvita/zagalnaserednya-osvita/navchalni-programi/navchalni-programidlya-pochatkovoyi-shkoli (Accessed 4 Feb. 2021). [in Ukrainian].

8. Navchalna prohrama dlia zahalnoosvitnikh navchalnykh zakladiv "Muzychne mystetstvo, 5-9 kl." [Curriculum for secondary schools "Music, grades 1-4"]. Available at: https://mon.gov.ua/ua/osvita/zagalnaserednya-osvita/navchalni-programi/navchalni-programi- dlya-pochatkovoyi-shkoli (Accessed 5 Feb. 2021). [in Ukrainian].

9. Slovnyk-dovidnyk muzychnykh terminiv (za knyhamy Yu. Yutsevycha) [Dictionary-reference book of musical terms (according to the books of Yu. Yutsevich)]. Available at: http://term.in.ua (Accessed 3 Feb. 2021). [in Ukrainian].

10. Filatova, L. (2012). Khorova tvorchist M. V. Lysenka u konteksti borotby intelihentsii proty zaborony ukrainskoi movy ta kultury [M.V. Lysenko's choral work in the context of the struggle of the intelligentsia against the ban on the Ukrainian language and culture]. Youth \& market. Monthly scientific-pedagogical journal. Drogobych,Vol.10 (93), pp. 72-76. [in Ukrainian].

11. Chahovets, V. (1985). M. V. Lysenko [M.V. Lysenko]. 28 p. [in Ukrainian].

12. Yurchenko, M.(1993). Lysenko M. Relihiini tvory dlia mishanoho khoru [Lysenko M. Religious works for mixed choir]. 36 p. [in Ukrainian].

Стаття надійшла до редакції 26.01.2021

УДК 378:373.31

DOI:

Катерина Степанюк, кандидат педагогічних наук, доцент кафедри початкової освіти Бердянського державного педагогічного університету

\section{ПРОФЕСІЙНА ПІДГОТОВКА МАЙБУТНІХ УЧИТЕЛІВ ПОЧАТКОВОЇ ШКОЛИ В КОНТЕКСТІ ПРІОРИТЕТІВ КОНЦЕПЦІї НУШ}

У статті розглядаються окремі аспекти професійної підготовки майбутніх учителів початкової школи в контексті пріоритетів Конщепчії НУШ. На прикладі курсу "Методика навчання сочіальної та здоров 'язбережувальної освітньої галузі” запропоновано варіант організації квазіпрофесійної діяльності та наведено зразки навчально-дослідницьких завдань для здобувачів першого рівня вищої освіти освітньоі програми 013 Початкова освіта. Доведено, що навчально-дослідниџькі завдання сприяють більш осмисленому й самостійному оволодінню студентами майбутньою педагогічною діяльністю учителями початкової школи.

Ключові слова: Нова украӥнська школа; професійний розвиток майбутніх учителів початкової школи; квазіпрофесійна діяльність; навчально-досліднищькі завдання.

Jim. 6.

Kateryna Stepanyuk, Ph.D.(Pedagogy), Associate Professor of the Primary Education Department Berdyansk State Pedagogical University

\section{PROFESSIONALTRAININGOFTHE FUTURETEACHERSOFPRIMARYEDUCATIONWITHIN THE CONTEXT OF PRIORITIESOFTHECONCEPT OF MODERN UKRAINIANSCHOOL}

Within the article certain aspects of the professional training of future teachers of primary school within the context of priorities of the Concept of Modern Ukrainian School are revealed.

It is determined that according to the educational program 013 Primary Education of the first level of higher education future teachers of primary school have to master knowledge, practical skills, means of teaching with in all educational fields of the State Standard of Primary Education (2018). Teachers also must successfully implement knowledge during the solving the pedagogical, educational and scientific tasks within the primary school.

The variant of organization of quasiprofessional activity on the basis of the course "Methodic of Teaching Social and Health-saving Educational Field" was proposed in the article. There samples of educational-research tasks for the students of the educational program 013 Primary Education are given.

It is given the definition of quasiprofessional activity which provides the ability to solve educationalresearching tasks with in real educational process at the primary school. It is proved that it is based on the practiceoriented theoretical teaching which takes place during the modeling of integral fragments of pedagogical activity. The quasi-professional activity within the course "Methodic of Teaching Social and Health-saving Educational Field" provides the ability to solve educational-research tasks in the real educational environment. 